\title{
Influence of technological parameters and type of drill bit on the accuracy of holes machining in carbon fibrous composites
}

\author{
Wpływ parametrów technologicznych i rodzaju wiertła \\ na dokładność obróbki otworów \\ w węglowych kompozytach włóknistych
}

\author{
PAWEŁ PIEŚKO \\ MAGDALENA ZAWADA-MICHAŁOWSKA *
}

The increasing interest in composite materials determines the conduct of research allowing to neutralize the negative effects of the machining process. The paper presents an analysis of the influence of technological parameters and the type of drill bits on the quality of drilled holes in carbon fibrous composites.

KEYWORDS: fibrous composite, drilling, delamination

In recent years, there has been a dynamic development of technologies for the production and shaping of composites. These materials are characterized by good mechanical properties at a relatively low weight, which is very important in modern industry, especially in aviation and automotive, and results in a growing interest in these materials [2, 3].

So-called fibrous composites, distinguished by high durability, are the most commonly used. In aviation and aeronautics, reinforced materials with good adhesion to the matrix and possibility of working under heavy loads are widely used. The properties of polymer composites are influenced by many factors, among which it is worth mentioning: type of the matrix, direction of the reinforcement's position in relation to the load direction and the operating temperature $[2,6]$.

Mechanical machining of composites causes big problems. One of the typical machining operations for these materials is drilling the holes. Because the openings usually play a mounting role, they are placed with high demands on the accuracy of the workmanship. Very often during drilling, there is an unfavorable phenomenon of the delamination, and sharp, uneven edges appear at the entry and exit of the tool (in the case of through-boring). To improve the accuracy of workmanship, tools with special geometry are used to machine these materials and appropriate ranges of technological parameters are selected [1, 4, 5, 7, 8].

The authors of papers $[5,7]$ indicate that the quality of holes can be determined on the basis of delamination coefficient, which is determined from the dependence:

$$
W_{D}=\frac{D_{\max }}{D_{\text {nom }}}
$$

where: $W_{D}$ - delamination coefficient, $D_{\max }$ - maximum diameter of delamination occurrence, $D_{\text {nom }}$ - nominal diameter of the hole (designations according to fig. 4)

\footnotetext{
* Dr inż. Paweł Pieśko (p.piesko@pollub.pl), mgr inż. Magdalena Zawada-Michałowska (m.michalowska17@pollub.pl) - Politechnika Lubelska
}

DOI: https://doi.org/10.17814/mechanik.2017.12.190

\section{Methodology}

The purpose of the study was to determine the impact of technological parameters and type of a drill on the accuracy of machining the openings and the amount of delamination generated in a selected composite material.

The holes were drilled on a AVIA VMC $800 \mathrm{HS}$ threeaxis machining center. The experiment used a sample (fig. 1a) made of polymer composite based on a carbon fiber reinforced with epoxy resin (CFRP) with dimensions: $190 \mathrm{~mm}$ (length) $\times 110 \mathrm{~mm}$ (width) $\times 3 \mathrm{~mm}$ (thickness). The pre-preg technology was used for its preparation.

Two types of drill bits (fig. 1b) with a diameter of $3 \mathrm{~mm}$ were used, i.e.:

- general Purpose Drill (VHM) by Format (11830300),

- carbide drill bit (VHM) from Garant coated with crystalline diamond (122512) for the machining of fibrous composites.

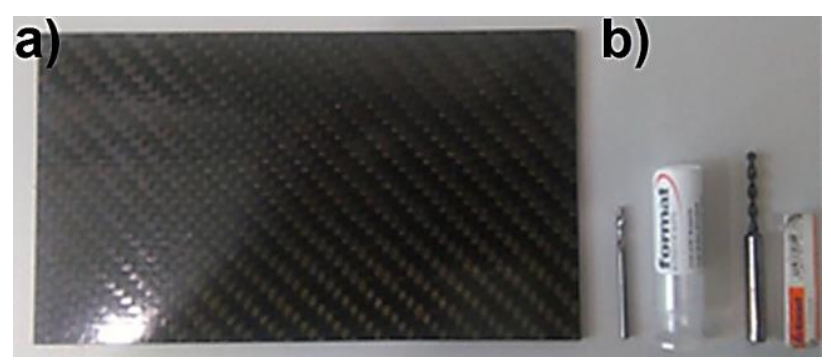

Fig. 1. Material and tools used: a) sample made of a polymer composite based on epoxy resin reinforced with carbon fiber, b) general purpose drill bit dedicated for machining the composite materials

Table I presents values of technological parameters used during the tests. The reference point for their selection was the guidelines from the Garant tool catalog, where the manufacturer recommends the following values: cutting speed $v_{c}=100 \mathrm{~m} / \mathrm{min}$ and feed rate per revolution $f=0.06 \mathrm{~mm} / \mathrm{rev}$. Three replications were made for each of the analyzed technological parameter configurations. 
TABLE I. Values of technological parameters used in the study

\begin{tabular}{|c|c|c|c|c|c|}
\hline Cutting depth, $a_{p}, \mathrm{~mm}$ & \multicolumn{5}{|c|}{1,5} \\
\hline Cutting speed, $v_{\mathrm{c}}, \mathrm{m} / \mathrm{min}$ & 40 & 60 & 80 & 100 & 120 \\
\hline $\begin{array}{c}\text { Rotational speed, } n \text {, } \\
\mathrm{rev} / \mathrm{min}\end{array}$ & 4244 & 6366 & 8488 & 10610 & 12732 \\
\hline Feed rate $f, \mathrm{~mm} / \mathrm{rev}$ & 0,02 & 0,04 & 0,06 & 0,08 & 0,10 \\
\hline
\end{tabular}

As part of the research, a total of 150 holes were drilled and measured. Each drill bit made 75 holes.

After machining the holes, an analysis of their accuracy was performed on the basis of measurements, for which were applied:

- optical scanner ATOS Capsule by GOM,

- Keyence VHX5000 digital measuring microscope.

Both measuring devices are characterized by high precision and are used in many branches of the machine industry.

\section{Test results}

In the first stage, the dimensional accuracy of holes after machining with two tested drill bit types was analyzed.

Tables II and III list the results of the hole diameters measurement performed by GOM optical scanner ATOS.

TABLE II. Diameter values of holes made with the general purpose drill bit

\begin{tabular}{|c|c|c|c|c|c|}
\hline $\begin{array}{r}\text { Cutting speed } v_{\mathrm{c}}, \\
\mathrm{m} / \mathrm{min}\end{array}$ & 40 & 60 & 80 & 100 & 120 \\
\hline Feed rate $f, \mathrm{~mm} / \mathrm{rev}$ & 2,92 & 2,92 & 2,92 & 2,91 & 2,92 \\
\hline 0,02 & 2,92 & 2,91 & 2,92 & 2,92 & 2,92 \\
\hline 0,04 & 2,92 & 2,92 & 2,92 & 2,91 & 2,92 \\
\hline 0,06 & 2,91 & 2,92 & 2,92 & 2,92 & 2,92 \\
\hline 0,08 & 2,91 & 2,92 & 2,91 & 2,91 & 2,92 \\
\hline 0,10 & & & & & \\
\hline
\end{tabular}

TABLE III. Diameter values of holes made with the dedicated drill bit for composites machining

\begin{tabular}{|c|c|c|c|c|c|}
\hline $\begin{array}{r}\text { Cutting speed } v_{\mathrm{c}}, \\
\mathrm{m} / \mathrm{min}\end{array}$ & 40 & 60 & 80 & 100 & 120 \\
\hline Feed rate, $f, \mathrm{~mm} / \mathrm{ren}$ & 2,94 & 2,93 & 2,93 & 2,93 & 2,93 \\
\hline 0,02 & 2,94 & 2,93 & 2,94 & 2,93 & 2,93 \\
\hline 0,04 & 2,93 & 2,93 & 2,94 & 2,93 & 2,94 \\
\hline 0,06 & 2,94 & 2,93 & 2,94 & 2,93 & 2,94 \\
\hline 0,08 & 2,94 & 2,93 & 2,94 & 2,95 & 2,95 \\
\hline 0,10 & & & & & \\
\hline
\end{tabular}

Measured values of diameters obtained after machining using both a general purpose carbide drill bit and a drill bit dedicated for machining the composites, are smaller than the nominal yalue of $3 \mathrm{~mm}$. In addition, slightly smaller deviations in the dimension were obtained in the case of a dedicated tool. The difference, however, is small and falls within the accuracy range of the measuring device.

Fig. 2 presents results of the delamination measurement of the composite obtained with the use of ATOS scanner (from the side of the tool entry), with marking of the holes, in which the removal of material occurred (purple color). Due to the possibilities of the GOM Inspect software, the maximum diameter of delamination was also measured.

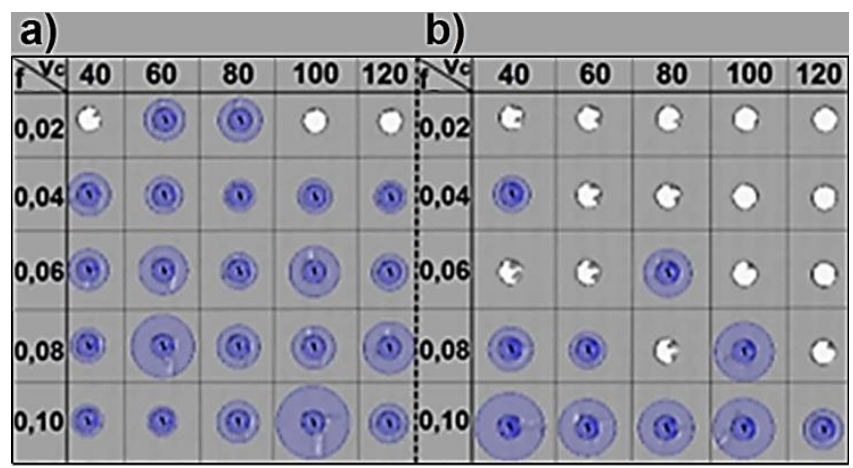

Fig. 2. Results of delamination measurement using the GOM optical scanner from GOM with marking of holes, in which the material was torn out: a) holes drilled with a general purpose drill bit, b) holes drilled with a drill bit dedicated for composites machining

It was noticed that much better quality of holes was obtained with a cemented carbide tipped with a crystalline diamond, which is dedicated to the machining of fibrous composites. It can be assumed that in the case of using this drill bit to $f=0.06 \mathrm{~mm} / \mathrm{rev}$ and all considered cutting speeds, delamination is practically absent or small.

In the case of a general purpose drill bit, the delamination is visible at almost all feed rate values. The exception is $f=0.02 \mathrm{~mm} / \mathrm{rev}$, for which, at $v_{c}=40,100$ and $120 \mathrm{~m} / \mathrm{min}$, no material delamination was noticed.

Tables IV and $\mathrm{V}$ set values of the material delamination coefficient at the entry of the drill bit into the fibrous composite.

TABLE IV. Values of delamination coefficient for a general purpose drill bit

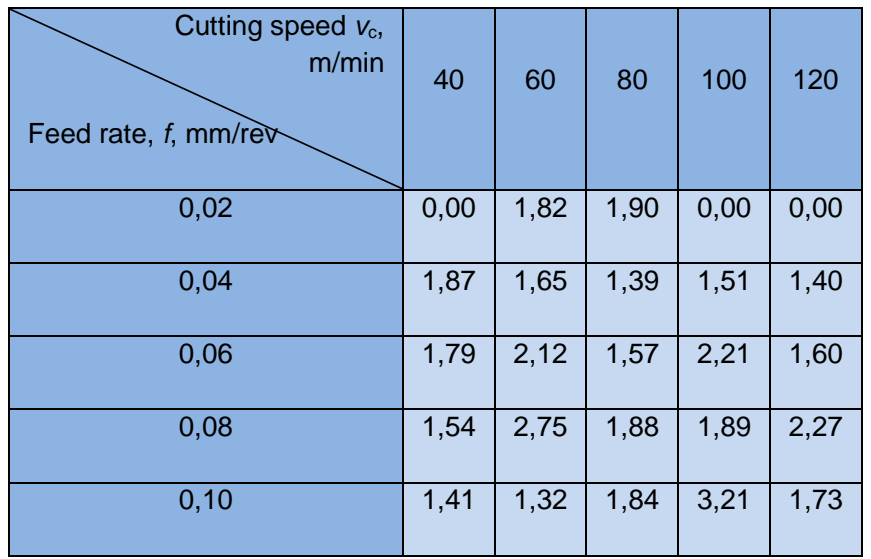


TABLE V. Values of delamination coefficient for a drill bit dedicated to the composites machining

\begin{tabular}{|c|l|l|l|l|l|}
$\begin{array}{r}\text { Cutting speed } v_{\mathrm{c}}, \\
\mathrm{m} / \mathrm{min}\end{array}$ & 40 & 60 & 80 & 100 & 120 \\
\hline Feed rate, $f, \mathrm{~mm} / \mathrm{rev}$ & & & & & \\
\hline 0,02 & 1,55 & 0,00 & 0,00 & 0,00 & 0,00 \\
\hline 0,04 & 0,00 & 0,00 & 2,03 & 0,00 & 0,00 \\
\hline 0,06 & 1,87 & 1,55 & 0,00 & 2,49 & 0,00 \\
\hline 0,08 & 2,91 & 2,42 & 2,33 & 2,57 & 1,69 \\
\hline 0,10 & & & & & \\
\hline
\end{tabular}

Analyzing the determined values of delamination coefficient and the results obtained from the ATOS optical scanner measurement, it was found that drilling with technological parameters recommended by the manufacturer, i.e. $v_{c}=100 \mathrm{~m} / \mathrm{min}$ and $f=0.06 \mathrm{~mm} / \mathrm{rev}$, allowed to obtain holes of high quality.

A clear influence of the feed rate on the accuracy of the holes' performance was also recorded. It is possible to drill with a tool dedicated to composites at a higher speed - in the analyzed case: $v_{c}=120 \mathrm{~m} / \mathrm{min}$ - using smaller feed rate values. For $f=0.1 \mathrm{~mm} / \mathrm{rev}$, regardless of the cutting speed, there was a phenomenon of delamination of the composite.

In addition, the complementary examinations were performed, consisting of the hole observation using the Keyence VHX5000 measuring microscope. Fig. 3 and fig. 4 show examples of images obtained for a dedicated tool; in fig. 3 there is a hole characterized by high accuracy, and in fig. 4 - a hole with delamination.

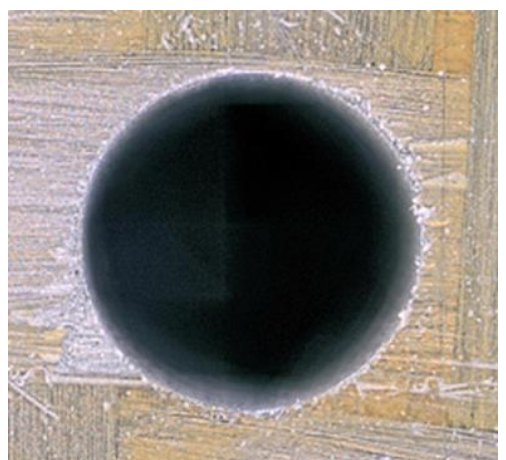

Fig. 3. Hole drilled with a dedicated tool; $v_{c}=120 \mathrm{~m} / \mathrm{min}$ and $f=$ $0.02 \mathrm{~mm} / \mathrm{rev}$

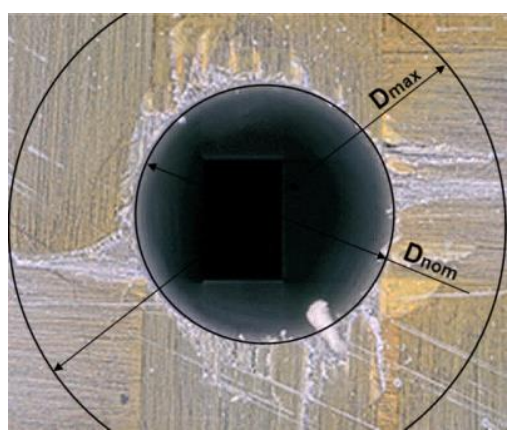

Fig. 4. Hole drilled with a dedicated tool; $v_{c}=100 \mathrm{~m} / \mathrm{min}$ and $f=$ $0.1 \mathrm{~mm} / \mathrm{rev}$
Analyzing the images from the measurement microscope, it can be concluded that the results obtained with the ATOS optical scanner were confirmed.

Fig. 5 and fig. 6 show spatial diagrams illustrating the relationship between the delamination coefficient and technological parameters such as cutting speed and feed rate. They refer to the general purpose tool (fig. 5) and the tool dedicated to the machining of composite materials (fig. 6).

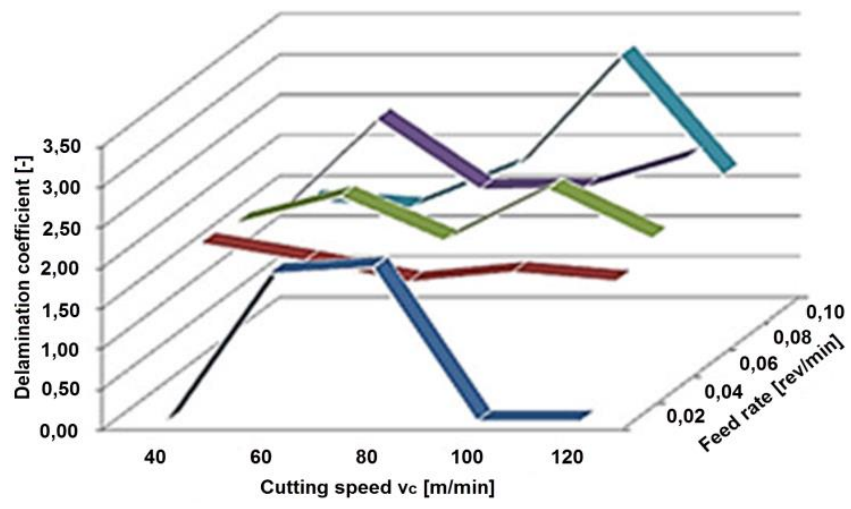

Fig. 5. Relationship between delamination coefficient and technological parameters (cutting speed and feed rate) for a general purpose drill bit

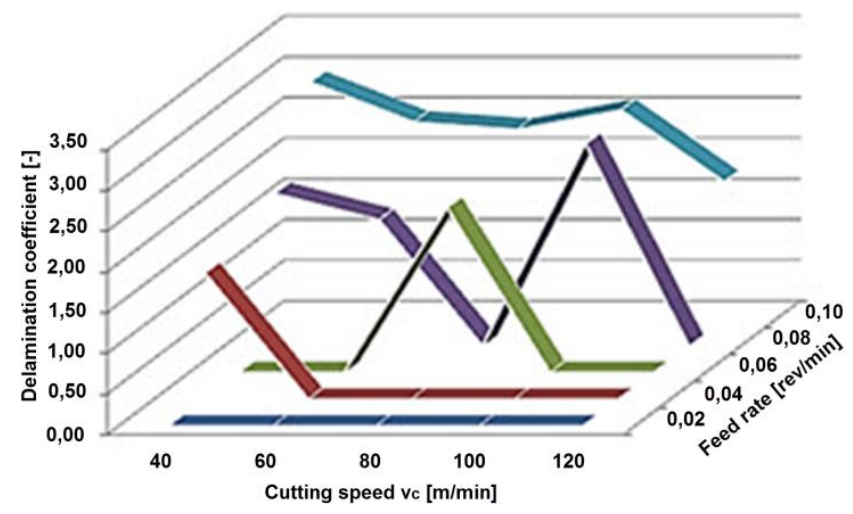

Fig. 6. Relationship between delamination coefficient and technological parameters (cutting speed and feed rate) for a drill bit dedicated to composites machining

In the case of a general purpose tool, the measurement results are difficult to interpret. A significant increase in the value of delamination coefficient along with the feed rate increase can be observed for both drill bits.

\section{Conclusions}

Studies and experimental tests have allowed to formulate the following important conclusions:

- Much better machining results were obtained with a tool dedicated to composites than with a general purpose drill bit.

- Selection of the right cutting data is important for the value of delamination.

- Feed rate and cutting speed values recommended by the manufacturer for a dedicated drill bit allow to minimize the risk of delamination.

- Increasing the feed rate translates into a remarkable increase in delamination. 
- Holes made with both drill bits have similar negative values of dimensional deviations.

- Dimensional errors result from the quality of workmanship (grinding) of drill bits.

\section{REFERENCES}

1. Banaszek M., Ivan K., Józwik J., Tofil A. „Wybrane aspekty obróbki skrawaniem polimerowych kompozytów włóknistych i oceny chropowatości powierzchni”. Postępy Nauki i Techniki. 15 (2011): pages 205-220.

2. Boczkowska A., Kapuściński J., Lindemann Z., WitembergPerzyk D., Wojciechowski S. „Kompozyty”. Warszawa: Oficyna Wydawnicza Politechniki Warszawskiej, 2003.

3. Boczkowska A., Krzesiński G. „Kompozyty i techniki ich wytwarzania". Warszawa: Oficyna Wydawnicza Politechniki Warszawskiej, 2016.

4. Cantero J.L., Diaz-Alvarez J., Fernandez-Perez J., Miguelez M.H. „Influence of cutting parameters on tool wear and hole quality in composite aerospace components drilling". Composite Structures. 178 (2017): pages 157-161.

5. Jaśkiewicz R. „Analiza wpływu parametrów procesu wiercenia na jakość uzyskiwanych otworów i właściwości mechaniczne kompozytów węglowych". Prace Instytutu Lotnictwa. 244, 3 (2016): pages 65-73.

6. Królikowski W. „Polimerowe kompozyty konstrukcyjne”. Warszawa: Wydawnictwo Naukowe PWN, 2012.

7. Leppert T., Paczkowski T., Polasik R., Serwacki D. „Delaminacja materiału kompozytowego włóknistego podczas wykonywania otworów". Mechanik. 10 (2016): pages 1422-1423.

8. Makhdum F., Phadnis V.A., Roy A., Silberschmidt V.V. „Drilling in carbon/epoxy composites: experimental investigations and finite element implementation". Composites. Part A: Applied Science and Manufacturing. 47 (2013): pages 41-51 